Yuriska : Jurnal Ilmu Hukum

https://journal.uwgm.ac.id/index.php/yuriska

P-ISSN: 2085-7616; E-ISSN: 2541-0962

Februari 2020, Vol. 12 No. 1

\title{
Kajian Hukum Atas Hubungan Antara Nasabah Dan Bank Ditinjau Dari Undang-Undang Nomor 10 Tahun 1998 Perubahan Atas Undang-Undang Nomor 7 Tahun 1992 Tentang Perbankan
}

\author{
Andriany Widie Astuti ${ }^{1}$, Wahyuni Safitri ${ }^{2}$ \\ E-mail: candra.hoo@gmail.com, Universitas Widya Gama Mahakam, Indonesia ${ }^{1}$ \\ E-mail: wahyunibun@gmail.com, Universitas Widya Gama Mahakam, Indonesia ${ }^{2}$
}

\begin{abstract}
The relationship between banks and customers is based on the two most related elements, namely law and trust. A bank can only carry out activities and develop its bank, if the community "believes" to place its money, on banking products that exist in the bank. The higher the trust of the community, the higher the public's awareness to save money with the bank and to use other banking services. Public trust is the main key to the development or failure of a bank, in the sense that without the trust of the community, then a bank will not be able to carry out its business activities. For business people, banks are the main complement in carrying out daily activities, controlling the entry and exit of funds and achieving success, and are usually in the form of checking accounts. Based on this, the writer wants to examine more deeply the relationship between customers and banks regarding account information, bank rights and customer rights, and is associated with existing regulatory regulations.
\end{abstract}

Keywords: Legal Assessment; Bank; Costumers.

\begin{abstract}
Abstrak
Hubungan antara bank dan nasabah didasarkan pada dua unsur yang paling terkait, yaitu hukum dan kepercayaan. Suatu bank hanya bisa melakukan kegiatan dan mengembangkan banknya, apabila masyarakat "percaya" untuk menempatkan uangnya, pada produk-produk perbankan yang ada pada bank tersebut. Semakin tinggi kepercayaan masyarkakat, maka akan semakin tinggi pula kesadaran masyarakat untuk menyimpan uangnya pada bank dan menggunakan jasa-jasa perbankan lain. Kepercayan masyarakat merupakan kunci utama bagi berkembang atau tidaknya suatu bank, dalam arti tanpa adanya kepercayaan dari masyarakat, maka suatu bank tidak akan mampu menjalankan kegiatan usahanya. Bagi pembisnis, bank merupakan pelengkap utama dalam menjalankan kegiatan harian, mengontrol keluar masuknya dana dan pencapaian keberhasilan, dan biasanya berupa rekening giro. Berdasarkan hal inilah penulis ingin mengkaji lebih dalam mengenai hubungan nasabah dan bank tentang informasi rekening, hak hak bank dan hak-hak nasabah, dan dikaitkan dengan peraturan perundang-undangan yang ada.
\end{abstract}

Kata kunci: Hubungan Hukum; Bank; Nasabah.

\begin{tabular}{l|l|l} 
DOI & $:$ & https://doi.org/10.24903/yrs.v12i1.866
\end{tabular}

\begin{tabular}{|l|l|l|}
\hline Received & $:$ & Januari 2020 \\
\hline Accepted & $:$ & Januari 2020 \\
\hline Published & $:$ & Februari 2020 \\
\hline Copyright Notice & $:$ & $\begin{array}{l}\text { Authors retain copyright and grant the journal right of first publication with the } \\
\text { work simultaneously licensed under a Creative Commons Attribution 4.0 } \\
\text { International License that allows others to share the work with an acknowledgement of }\end{array}$ \\
\hline the work's authorship and initial publication in this journal.
\end{tabular}

(C) (i) 


\section{PENDAHULUAN}

Menurut Soeroso yang dimaksud dengan hubungan hukum ialah hubungan antara dua atau lebih subjek hukum. Dalam hubungan hukum ini hak dan kewajiban pihak yang satu berhadapan dengan hak dan kewajiban pihak yang lain. ${ }^{1}$ Hubungan hukum adalah perikatan yang lahir akibat peristiwa hukum. Peristiwa hukum terjadi karena undang-undang dan perjanjian. $^{2}$

Hukum mengatur hubungan antara orang yang satu dengan orang yang lain, antara orang dengan masyarakat, antara masyarakat yang satu dengan masyarakat yang lain. Jadi hubungan hukum terdiri atas ikatan-ikatan antara individu dengan individu dan antara individu dengan masyarakat dan seterusnya. Dengan kata lain hubungan hukum terdiri atas ikatan-ikatan antara individu dengan individu dan antara individu dengan masyarakat dan seterusnya. Dengan kata lain hubungan hukum adalah hubungan yang diatur oleh hukum. Adapun hubungan yang tidak diatur oleh hukum bukan merupakan hubungan hukum.

Hubungan hukum dapat terjadi diantara sesama subyek hukum dan antara subyek hukum dengan barang. Hubungan antara sesama subyek hukum dapat terjadi antara seseorang dengan seorang lainnya, antara seseorang dengan suatu badan hukum, dan anatara suatu badan hukum dengan badan hukum lainnya. Sedangkan hubungan antara subyek hukum dengan barang berupa hak apa yang dikuasai oleh subyek hukum itu atas barang tersebut baik barang berwujud dan barangbergerak atau tidak bergerak. ${ }^{3}$

Bank merupakan suatu lembaga perantara keuangan (financial intermediary) antara unit perekonomian yang surplus (kelebihan dana) kepada unit perekonomian yang mengalami defisit (kekurangan dana). Sehingga dapat dikatakan bahwa bank merupakan inti dari sistem keuangan setiap negara. Pasal 1 butir 2 Undang-Undang Nomor 10 tahun 1998 Tentang Perbankan dijelaskan bahwa "Bank adalah badan usaha yang menghimpun dana dari masyarakat dalam bentuk simpanan dan menyalurkannya kepada masyarakat dalam bentuk kredit dan/atau bentuk-bentuk lainnya dalam rangka meningkatkan taraf hidup rakyat banyak".

Dikutip pada buku Hukum Perbankan, yang ditulis oleh Sentosa Sembiring yang menyatakan bahwa "Bank menjadi inti sari dari sistem keuangan setiap negara, karena merupakan salah satu motor penggerak pembangunan seluruh bangsa, dan dapat menunjang

\footnotetext{
${ }^{1}$ R. Soeroso, Pengantar IImu Hukum, Cet. VII (Jakarta: Sinar Grafika, 2005).

2 R. Soeroso.

${ }^{3}$ Peter Mahmud Marzuki, Penelitian Hukum (Jakarta: Kencana Prenada Media Group).
} 
pelaksanaan pembangunan nasoional dalam rangka meningkatkan pemerataan, pertumbuhan ekonomi dan stabilitas nasional kearah peningkatan kesejahteraan rakyat. Bank merupakan lembaga keuangan yang menjadi tempat bagi perusahaan, lembaga pemerintah, swasta maupun perorangan menyimpan dananya, melalui kegiatan usaha perbankan."4

Dari pernyataan ini sangatlah jelas bahwa peran perbankan sebagai penghimpun dan penyalur dana ke masyarakat secara efektif dan efisien, dengan berasaskan demokrasi ekonomi untuk mendukung pembangunan nasional dan berujung dengan pertumbuhan ekonomi, stabilitas nasional serta peningkatan taraf hidup. Sentosa Sembiring pada bagian lain menyatakan bahwa "Bank merupakan lembaga keuangan yang menjadi wadah bagi badan usaha, lembaga pemerintah, swasta maupun orang pribadi selain sebagai tempat menyimpan dana dan sebagai sarana dalam melakukan berbagai transaksi keuangan. Lewat lembaga pengumpulan dana tersebut, bank dapat menyalurkan kembali dana yang sudah terkumpul kepada masyarakat melalui pranata hukum perkreditan. Disamping fungsi yang telah disebutkan di atas, bank juga memberikan berbagai jasa perbankan yang dibutuhkan oleh nasabah maupun masyarakat pada umumnya." ${ }^{5}$

Menurut Kasmir, Bank secara sederhana dapat diartikan sebagai "Lembaga keuangan yang kegiatan utamanya adalah menghimpun dana dari masyarakat dan menyalurkannya kembali dana tersebut ke masyarakat serta memberikan jasa bank lainnya" " Bank adalah lembaga keuangan kredit yang mempunyai tugas utama memberikan kredit disamping memberikan jasa-jasa lain di bidang keuangan. ${ }^{7}$ Berdasarkan uraian diatas bahwa penulis sepakat dengan pernyataan Kasmir yang menyatakan bahwa bank adalah lembaga keuangan yang kegiatan utamanya adalah menghimpun dana dari masyarakat dan menyalurkannya kembali dana tersebut ke masyarakat serta memberikan jasa bank lainnya. Bank merupakan suatu badan usaha formal yang didirikan dengan tujuan untuk masyarakat menyimpan uang dengan aman dan keberadaannya dapat membantu kegiatan perekonomian di suatu negara. Dari beberapa definisi yang di uraikan tersebut maka dapat diambil suatu kesimpulan bahwa bank sebagai pencipta uang (uang kartal dan giral) dan sebagai penyalur simpanan-simpanan dari masyarakat.

Mengenai sifat hubungan hukum bank dengan nasabahnya, maka di Indonesia pada dasarnya berlaku hukum perdata yang dapat dicari dalam Kitab Undang-Undang Hukum

\footnotetext{
${ }^{4}$ Sentosa Sembiring, Hukum Perbankan (Bandung: Mandar Maju, 2002).

${ }^{5}$ Sembiring.

${ }^{6}$ Kasmir, Bank Dan Lembaga Keuangan Lainnya, Revisi (Jakarta: RajaGrafindo Persada, 2008).

${ }^{7}$ Bambang Riyanto, Dasar-Dasar Pembelanjaan Perusahaan, IV (Yogyakarta: BPFE, 2013).
} 
Perdata (Burgerlijk Wetboek) terutama Buku Ketiga tentang Perikatan dan tentang Pinjam Meminjam. Juga dapat ditemukan dalam Kitab Undang-Undang Hukum Dagang (Wetboek van Koophandel) terutama mengenai cek, wesel, dan warkat-warkat lainnya. Dalam UndangUndang Nomor 10 Tahun 1998 Perubahan atas Undang Undang Nomor 7 Tahun 1992 Tentang Perbankan banyak pihak-pihak yang dapat menghubungkannya untuk mencari jawaban terhadap persoalan perbankan terutama dalam hubungan pokok antara Bank dengan Nasabahnya. ${ }^{8}$ Prinsip Kesetaraan, kesukarelaan, kebebasan, dan prinsip universal sebagaimana ditentukan pula oleh Pasal 1320 Kitab Undang undang Hukum Perdata dalam menentukan sah tidaknya suatu kontrak, maka dalam hubungan hukum bank dengan nasabahnya prinsip transparansi juga menjadi prinsip yang menentukan seorang nasabah dapat melaksanakan transaksinya dengan pihak bank atau tidak. ${ }^{9}$

Bagi pengusaha bank merupakan pelengkap utama dalam menjalankan kegiatan harian, mengontrol keluar masuknya dana dan pencapaian keberhasilan, dan biasanaya berupa rekening giro. Rekening Giro merupakan rekening yang penarikannya dapat dilakukan setiap saat dengan menggunakan cek, bilyet giro, sarana perintah pembayaran lain atau dengan cara pemindah bukuan. Banyak perusahaan membutuhkan jasa simpanan giro ini untuk membantu melancarkan bisnis dalam hal transaksi keuangan. Terkait pembukaan rekening giro ada prosedur yang sudah ditetapkan oleh bank yang bersangkutan, akan tetapi sebagian besar masyarakat belum memahami simpanan giro yang ditawarkan oleh bank baik itu prosedur dan syarat-syarat pembuatan rekening giro, serta jenis rekening giro yaitu rekening giro perorangan dan rekening giro perusahaan.

Berdasarkan hal ini penulis ingin mengkaji lebih dalam mengenai hubungan nasabah dan bank tentang informasi rekening, hak hak bank dan hak-hak nasabah, dikaitkan dengan peraturan peundang-undangan yang ada, maka dari itu penulis tertarik untuk mengangkat permasalahan mengenai bagaimana kajian hukum atas hubungan antara nasabah dan bank ditinjau dari Undang-Undang Nomor 10 Tahun 1998 Tentang Perubahan Atas UndangUndang Nomor 7 Tahun 1992 Tentang Perbankan dan latar belakang bank meminta informasi rekening nasabah.

\section{METODE PENELITIAN}

Jenis penelitian yang peneliti gunakan dalam penulisan ini yaitu metode penelitian hukum normatif (normative law research) menggunakan kasus normatif berupa produk

\footnotetext{
${ }^{8}$ Gunarto Suhardi, Usaha Perbankan Dalam Perspektif Hukum (Yogyakarta: Kanisius, 2003).

${ }^{9}$ Suhardi.
} 
perilaku hukum, misalnya mengkaji undang-undang. Pokok kajiannya adalah hukum yang dikonsepkan sebagai norma atau kaidah yang belaku dalam masyarakat dan menjadi acuan perilaku setiap orang, Sehingga penelitian hukum normatif berfokus pada inventarisasi hukum positif, asas-asas dan doktrin hukum, penemuan hukum dalam perkara in concreto, sistematik hukum, taraf sinkronisasi, perbandingan hukum dan sejarah hukum. ${ }^{10}$

Data yang dibutuhkan dalam penelitian ini antara lain data primer adalah data yang diperoleh secara langsung berupa keterangan-ketrangan dan pendapat dan kenyataankenyataan yang ada dilapangan dan observasi. ${ }^{11}$ Dan data sekunder adalah data yang diperoleh dari studi kepustakaan dan mempunyai kekuatan hukum mengikat, yang terdiri dari bahan baku primer, bahan hukum sekunder dan bahan hukum tersier. ${ }^{12}$

Tekhnik pengumpulan data yang digunakan berupa studi kepustakaan dan studi lapangan, melalui wawancara di beberapa tempat yaitu Bank Indonesia Provinsi Kalimantan Timur, Otoritas Jasa keuangan Provinsi Kalimantan Timur, dam PT Bank HSBC Samarinda. Data yang diperoleh dari Kepustakaan dan lapangan dianalisis secara kualitatif, maksudnya analisis yang dilakukan dengan cara memahami dan merangkai data yang telah dikumpulkan secara sistematis.

\section{PEMBAHASAN}

Undang-Undang Perbankan Nomor 10 Tahun 1998 Pasal 1 angka (2), menyebutkan bahwa bank adalah badan usaha yang menghimpun dana dari masyarakat dalam bentuk simpanan dan menyalurkannya kepada masyarakat dalam bentuk kredit dan atau bentuk lainnya dalam rangka meningkatkan taraf hidup rakyat banyak.

Berdasarkan dua fungsi utama dari bank tersebut yaitu fungsi penghimpunan dana dan fungsi penyalur dana (kredit), maka terdapat dua hubungan hukum antara bank dan nasabah yaitu:

1. Hubungan hukum antara bank dan nasabah penyimpan dana.

2. Hubungan hukum antara bank dan nasabah debitur

Kegiatan usaha yang dapat dilakukan oleh bank lebih banyak menampilkan aspek hukum perdata, yaitu hubungan antara 2 (dua) subyek hukum (penyandang hak dan kewajiban), yaitu bank dan nasabah. Sebagaimana diketahui hubungan hukum terjadi apabila antara dua pihak atau lebih tercipta hubungan yang menimbulkan hak dan kewajiban bagi pihak-pihak yang terkait,

\footnotetext{
${ }^{10}$ Abdulkadir Muhammad, Hukum Dan Penelitian Hukum, Cet. I (Bandung: PT. Citra Aditya Bakti, 2004).

${ }^{11}$ Bambang Sunggono, Metodologi Penelitian Hukum (Jakarta: Rajawali Press, 2016).

${ }^{12}$ Bahder Johan, Metode Penelitian Hukum (Semarang: Mandar Maju, 2004).
} 
Sebagai contoh dalam pemberian kredit, hubungan antara bank dan nasabah menimbulkan hak bagi nasabah di satu pihak untuk memperoleh fasilitas kredit dan wajib mengembalikan pada waktunya, di lain pihak kewajiban bank untuk menyediakan fasilitas kredit yang diminta pada waktu yang tepat dan berhak mendapatkan pembayaran kembali pada waktu yang telah diperjanjikan.

Dalam kegiatan penghimpunan dana masyarakat, baik dalam bentuk deposito maupun tabungan tidak dibuat secara jelas dan rinci. Di dalam Undang-Undang Nomor 10 Tahun 1998 tentang Perbankan, tidak ditemui ketentuan yang mengatur secara tegas perihal hubungan hukum antara bank dan nasabahnya. Namun dari beberapa ketentuan dapat disimpulkan bahwa hubungan hukum antara bank dan nasabah diatur oleh suatu perjanjian.

Salah satu aspek penting dalam bahasan hubungan hukum antara nasabah dengan bank adalah perjanjian antara keduanya, yang biasanya dibuat secara sepihak oleh bank. Seiring dengan waktu, maka perjanjian sebagaimana diatur dalam KUHPerdata yang dianut oleh Indonesia selama ini mengalami pergeseran. Di antara pegeseran dalam pembuatan perjanjian adalah perjanjian antara produsen dan konsumen yang salah satunya adalah antara bank dan nasabah.

Sebagaimana diketahui, azas kebebasan berkontrak yang menjadi landasan hukum perjanjian, setiap orang bebas untuk membuat perjanjian mengenai hal atau obyek apapun dan dalam bentuk yang bagaimanapun. Pembatasan yang diatur undang-undang adalah bahwa kebebasan dimaksud dapat dilakukan, asal tidak bertentangan dengan Undang-Undang, kesusilaan dan ketertiban umum. Kebebasan yang diberikan Undang-Undang mencakup pula dengan siapa seseorang tersebut akan mengadakan perjanjian, bahkan juga untuk tidak mengadakan perjanjian

Dewasa ini ada kecenderungan makin memperlihatkan bahwa banyak perjanjian di dalam transaksi bisnis yang terjadi dilakukan bukan melalui suatu proses negosiasi yang seimbang di antara para pihak, tetapi perjanjian bisnis tersebut dilakukan oleh pihak yang satu telah menyiapkan suatu syarat baku pada suatu formulir perjanjian yang sudah dipersiapkan lebih dulu atau sudah dicetak dan kemudian diserahkan kepada pihak yang lain untuk disetujui dengan hampir tidak memberikan kebebasan sama sekali kepada pihak yang lain untuk melakukan negosiasi atas syarat-syarat yang disampaikan. Perjanjian yang demikian dinamakan perjanjian standar atau perjanjian baku atau perjanjian adhesi.

Perjanjian baku ini juga dikenal dalam transaksi di bidang perbankan, khususnya dalam produk tabungan. Pada produk-produk tesebut pihak bank telah menyiapkan segala 
persyaratannya secara baku dalam bentuk formulir produk perbankan, dengan pengertian posisi deposan (nasabah) harus menyetujui atas segala persyaratan yang terdapat pada formulir produk perbankan tersebut. Nasabah harus tunduk dengan segala persyaratan yang ditentukan oleh bank. Penggunaan kontrak baku ini karena adanya perbuatan-perbuatan hukum atau perjanjian sejenis yang terjadi secara berulang-ulang disertai dengan isi dan syarat-syarat perjanjian yang selalau sama, yang mungkin berbeda terletak pada subjek dan objek.

Di dalam praktek, perjanjian baku atau perjanjian standar ini tumbuh sebagai perjanjian tertulis dalam bentuk formulir, perbuatan-perbuatan hukum sejenis yang selalu terjadi secara berulang-ulang dan teratur bisa melibatkan banyak orang atau pihak sehingga menimbulkan kebutuhan untuk mempersiapkan isi perjanjian terlebih dahulu, kemudian dibakukan sehingga memudahkan penyediaan setiap saat jika masyarakat membutuhkannya.

Lahirnya bentuk perjanjian baku atau perjanjian standar ini berlandaskan pada asas hukum perdata yang menganut sistem terbuka yang memberikan kebebasan yang seluasluasnya kepada masyarakat untuk mengadakan perjanjian. Dan setiap perjanjian yang dibuat tersebut mengikat para pihak.

Hakikat dari asas kebebasan berkontrak dan asas kesepakatan apabila posisi tawar menawar (bargaining position) para pihak adalah setara dalam arti para pihak dapat saling mengemukakan apa yang dikehendaki masing-masing. Dalam praktek perbankan, pada umumnya bank telah membuat formulir tersendiri. Dalam formulir tersebut telah tertera segala persyaratan-persyaratan yang harus ditentukan oleh bank. Apabila dilihat dari sudut pandang ini, jelas bagi nasabah hanya ada dua pilihan yakni apakah setuju atau tidak terhadap persyaratan yang telah ditentukan oleh bank.

Hubungan hukum yang timbul dalam kegiatan penghimpunan dana masyarakat tidak diwujudkan dalam suatu perjanjian, akan tetapi adanya suatu hubungan hukum hanya dapat dipersangkakan dengan melihat beberapa petunjuk berupa naskah atau perbuatan pihak-pihak yang terkait dalam suatu prosedur kerja yang harus dilalui. Dalam kegiatan penghimpunan dana masyarakat, baik melalui deposito maupun tabungan tidak dibuat perjanjian yang menetapkan hak dan kewajiban para pihak dengan jelas dan rinci. Dilihat secara hukum praktek ini sah dan mengikat para pihak dan warkat-warkat yang digunakan dapat membuktikan adanya hubungan hukum.

Basis hubungan hukum antara bank dan nasabah adalah hubungan kontraktual. Hubungan kontraktual ini terjadi pada saat nasabah menjalin hubungan hukum dengan bank, 
seperti nasabah mengisi dan menandatangani aplikasi permohonan untuk membuka rekening, menabung atau mendepositokan uang nasabah.

Aplikasi atau permohonan diakhiri dengan suatu klausula yang menyatakan kesediaan calon nasabah mentaati peraturan-peraturan yang dikeluarkan bank, baik yang sudah ada maupun yang akan ditetapkan kemudian. Klausula yang bunyinya mengikatkan diri pada serangkaian ketentuan pada hakikatnya menimbulkan akibat yang sama dengan suatu perjanjian. Hal tersebut terbukti bahwa bank kemudian menyerahkan buku tabungan atau bilyet deposito kepada nasabah sebagai suatu tanda persetujuan atas permohonan yang diajukan, dapat dikatakan terjadi suatu persetujuan secara diam-diam. Dalam buku tabungan dan bilyet deposito tercantum pula beberapa ketentuan dan syarat-syarat yang dibuat dalam bentuk yang sudah baku. Perjanjian yang dibuat dalam menabung dan mendepositokan uang tidak jelas merumuskan hak dan kewajiban pihak-pihak.

Untuk mengetahui hak dan kewajiban antara bank dan nasabah, harus dilihat lebih dulu jenis layanan jasa apa yang digunakan oleh nasabah. Hal ini penting, karena layanan jasa yang diberikan oleh dunia perbankan sudah demikian luas sehingga persyaratan yang tercantum dalam standar kontrak yang digunakan oleh bank juga bervariasi. Artinya tergantung dari jenis layanan jasa yang digunakan. Misal persyaratan yang tercantum dalam pembukaan rekening giro, tabungan, deposito dan perjanjian kredit, mempunyai persyaratan tersendiri.

Persyaratan yang harus dipenuhi bila hendak menjadi penabung suatu bank, tergantung dari persyaratan yang ditentukan oleh bank yang bersangkutan. Disebut demikian, karena persyaratan antara satu bank dengan bank lainnya berbeda satu sama lain. Masingmasing bank mempunyai produk tersendiri yang satu sama lain mempunyai ciri tersendiri dan selalu menawarkan program yang lebih unggul dan kompetitif dalam menghadapi persaingan di dunia perbankan.

Untuk suatu hubungan hukum antara nasabah dengan bank dalam pembukaan rekening ada tiga ketentuan, seperti yang dikemukakan oleh Tri Widiyono, Aspek Hukum Operasional Transaksi Produk Perbankan di Indonesia, simpanan, jasa dan kredit, yaitu:

1. Ketentuan yang tedapat dalam aplikasi

2. Ketentuan yang tedapat pada syarat-syarat umum pembukaan rekening

3. Ketentuan yang terdapat pada produk yang digunakan oleh nasabah.

Apa yang dikemukakan diatas merupakan penunjukan terhadap ketentuan-ketentuan formal yang mengatur mengenai hubungan hukum antara nasabah dengan bank. Dan yang 
perlu diketahui, bank sebaiknya memberi tahu kepada masyarakat tentang hak dan kewajibannya dalam mengadakan hubungan hukum dengan bank, sebab nasabah pada dasanya percaya kepada bank. Atas dasar kepercayaan, sekalipun perjanjian-perjanjian antara nasabah dengan bank tersebut menguntungkan secara sepihak bagi bank, tetapi masyarakat perlu mendapat informasi terkait hak dan kewajiban sebagai akibat dari adanya hubungan hukum antara nasabah dengan pihak bank.

Meskipun hak dan kewajiban tersebut tidak tercantum secara jelas didalam brosur atau leaflet pembukaan rekening nasabah di bank dan tidak dibicarakan dengan negosiasi dalam pembukaan rekening, akan tetapi secara umum dapat dilihat hak dan kewajiban antara bank dan nasabah. Hal lain yang menjadi penting adalah mengdukasi nasabah, sehingga nasabah mengerti benar produk perbankan apa yang diperlukan, positif negatifnya serta layanan apa saja yang didapatkan.

Agar kepercayaan nasabah terhadap bank terjaga. Dalam edukasi, dengan bahasa yang baik dan mudah dimengerti maka nasabah akan merasa nyaman dengan layanan bank. Kehati-hatian bank dalam menyampaikan edukasi tentu saja diperlukan mengingat sebagian besar nasabah di Indonesia masih berpendidikan rendah. Edukasi perbankan kepada nasabah sudah dilakukan dalam berbagai bentuk media, baik secara rutin maupun situasional. Beberapa media edukasi perbankan seperti frontliner, call center, pameran media promosi seperti brosur, leaflet, starter pack product, website dan media jejaring sosial. Bahwa dasar utama kegiatan perbankan adalah kepercayaan, baik dalam penghimpun dana maupun penyaluran dana.

Lembaga perbankan memiliki aturan yang berbeda-beda dalam menjaga keberlangsungan perusahaan (bank). Informasi terkait nasabah merupakan hal penting yang wajib dimiliki oleh bank. Akan tetapi, apabila terjadi akuisisi antar bank, data nasabah dari bank sebelumnya tetap dapat dipercaya. Kalaupun pada akhirnya bank yang melakukan akuisisi memerlukan pembaharuan data nasabah, akan lebih baik bila hal tersebut disampaikan secara terbuka kepada nasabah dengan disertai penjelasan yang dapat dipahami oleh nasabah.

Latar belakang bank meminta informasi rekening nasabah bermaksud melakukan pembaharuan data dan informasi rekening nasabah yang bersangkutan, terlebih nasabah tersebut merupakan hasil dari akuisi dari bank sebelumnya. Meskipun berdasarkan Peraturan Bank Indonesia Nomor 3/10/PBI/2001, tentang Penerapan Prinsip Mengenal Nasabah (Know Your Costumer Principles), bahwa prinsip mengenal nasabah adalah prinsip yang diterapkan 
bank untuk mengetahui sejauh mungkin identitas nasabah serta memantau kegiatan transaksi nasabah termasuk kegiatan pelaporan transaksi mencurigakan, yang meliputi nasabah biasa (face to face coutumer), maupun nasabah bank tanpa berhadapan secara fisik (non face to face costumer), seperti nasabah yang melakukan transaksi melalui telepon, surat-menyurat, dan electronic banking.

Pembaharuan data dan informasi tersebut merupakan upaya lembaga perbankan untuk menjaga kesehatan dari lembaga tersebut dan melindungi nasabah. Agar di kemudian hari tidak terjadi kemungkinan yang dapat merugikan kedua belah pihak.

\section{KESIMPULAN}

Kesimpulan dari penelitian ini adalah hubungan hukum antara nasabah dan lembaga perbankan berdasarkan kepercayaan. Bank berhak untuk memperoleh data dan informasi dari nasabah yang bersangkutan, begitu pula nasabah berhak mendapatkan kejelasan informasi, hak dan kewajiban, serta edukasi terhadap proses perbankan yang terjadi. Pembaharuan data dan informasi nasabah dilakukan untuk memvalidasi data yang telah ada sebelumnya.

\section{REFERENSI}

Johan, Bahder, Metode Penelitian Hukum (Semarang: Mandar Maju, 2004)

Kasmir, Bank Dan Lembaga Keuangan Lainnya, Revisi (Jakarta: RajaGrafindo Persada, 2008)

Marzuki, Peter Mahmud, Penelitian Hukum (Jakarta: Kencana Prenada Media Group)

Muhammad, Abdulkadir, Hukum Dan Penelitian Hukum, Cet. I (Bandung: PT. Citra Aditya Bakti, 2004)

R. Soeroso, Pengantar Ilmu Hukum, Cet. VII (Jakarta: Sinar Grafika, 2005)

Riyanto, Bambang, Dasar-Dasar Pembelanjaan Perusahaan, IV (Yogyakarta: BPFE, 2013)

Sembiring, Sentosa, Hukum Perbankan (Bandung: Mandar Maju, 2002)

Suhardi, Gunarto, Usaha Perbankan Dalam Perspektif Hukum (Yogyakarta: Kanisius, 2003)

Sunggono, Bambang, Metodologi Penelitian Hukum (Jakarta: Rajawali Press, 2016) 